\title{
The Study on the Promotion Strategy of Army Civilian Faculty's Teaching Ability in the Military Academy from an Individual Perspective
}

\author{
He Lixin \\ Non-commissioned Officer School of Army Academy of \\ Armored Forces \\ Changchun, China \\ liberty1017@sina.com
}

\author{
Jin Meng \\ Non-commissioned Officer School of Army Academy of \\ Armored Forces \\ Changchun, China \\ 245593861@qq.com
}

\author{
Sun Jingxue \\ Non-commissioned Officer School of Army Academy of Armored Forces \\ Changchun, China \\ 284826176@qq.com
}

\begin{abstract}
With the establishment of the Army Civilian Policy since 2005, the number of Army Civilian community has witnessed an increasing trend, especially in military academies. Therefore, the teaching abilities of civilian posts have aroused great attention, but there is no systematic analysis on the promotion of the teaching abilities of civilian posts in army academies has been conducted. This paper aims to provide a systematic promotion strategy for army's cultural knowledge system and contribute to the cultivation of high-level military talents. Through the connotation analysis of teaching ability, the connotation of the teaching abilities of civilian posts has been summaried. Besides, based on the features of civilian posts and the most effective teaching theory, cognitive-developmental theory, psychological need theory and national defense need theory have been put forward. Based on the above content, this paper proposes the strategy of how to promote the teaching abilities in military academies from an individual perspective on the basis of adaptability, knowledge, research and image of individual.
\end{abstract}

Keywords-Promotion strategy; Army civilian; Teaching ability; Military academy

\section{INTRODUCTION}

Since 2015 the 70 anniversary of the victory of the world anti-fascist war where start to carry out the most thorough and influential reform in Chinese military force, president $\mathrm{Xi}$ announced that Chinese military would disarm thirty thousand of servicemen. The disarmament involves different categories of military academies, field action units, military hospitals belonging to army, naval and air force. Considering of completing the military personnel structure, military employs many army civilians who are coming from local universities and local government civilians or enterprises and who are expert in some aspects. As the cradle of military talents, military academy carries on the duty of cultivating qualified soldiers with high comprehensive capabilities. But the civilians are coming from different social field, who are still different with military servicemen, and there are still some aspects that need to change and adapt to military environment. Regarding the need of cultivating high level military talents and the reality of military, it is necessary to search for a reasonable promotion strategy of army civilian faculties' teaching abilities. Especially in present situation, social developing pace is so fast and science and technology in each aspect experiences innovative development. Meanwhile, artificial intelligence grows quickly. To strengthen Chinese national defense, the civilians need quickly to adjust their position to the military reality. Civilian's social status has been greatly improved and has been recognized by civilian's policy. In the new era, this group also expects to devote to military development and can play a significant role in military construction. The paper applies the methods of literature study, empirical study to discuss and analysis the relatively theory, current situation and policy implement for encouraging the promotion of civilian faculty's teaching ability.

\section{The ANALYSIS OF CIVILIAN Post TEACHING ABILITY}

\section{A. The Connotation of Post Working Ability}

Post working ability is the combination of post and ability. At the very beginning, the post is the original personnel management foundation and it is the core work of human resource. Therefore, the post working ability can be described as the melting form of post and the matter they would engage in. In a working organization, if the function of an organization varied, the structure will also different. It means basically the organic combination people with position. The tasks of a position need equivalent qualified person to carry on the duty. The faculty need equivalent professional major knowledge, skills needed and certain position qualification and condition. On the one hand, post itself is a kind of labor, on the other hand when it is evaluated from society angle it is a kind of social relationship. In this paper, the definition "post" in the army civilian's post teaching ability means the work that a person engages in. 
The connotation of ability or connotation of capability: the coverage of connotation of ability or capability can cover a wide variety of range. In many well-known dictionaries, the ability or capability can be illustrated as the talents and the ability dealing with things. When mentioning ability, it is naturally understood as common ability and special ability. For the further development, ability also should have recreation and innovative ability. The ability occurs in this paper refer to the ability that is the necessity to own these comprehensive qualities for a position. In military academy, the ability or capability can be described as the ability that can guarantee a position can be well done by a person owning definite capabilities.

For post teaching, ability is composed of three elements---post, teaching and ability. Post teaching ability mainly emphasizes on its post. Based on previous statement and comparison, post teaching ability has a strong inclination of position. Post teaching ability for a person, it can refer to a person's knowledge accumulation. For experience, it can refer to a person's practice experience and the experience acquired from practice experience. If Knowledge cannot output from accumulated brain stored information, it cannot be looked as ability. Ability is the central status in academy teaching. For military civilian, they have accumulated enough knowledge that is capable of a qualified teacher, but how to apply the knowledge in teaching, and achieve success to complete tasks carried out. It is the problem of ability.

\section{B. The Connotation and Construction of Army Civilian Posts' Working Ability}

on November13- 14, the year of 2018, Central Military Committee Institutional reform conference is held in Beijing, President xi emphasis that policy, military relationship, military practice, military development all have great significance in realizing military strong and Chinese dream of achieving the great rejuvenation of the Chinese nation. The Chinese dream is to make China strong. Without a strong military, a country can be neither safe nor strong. In the new historical period, to cultivate the combat effectiveness as the sole and fundamental standard, it demands the fundamental academy teaching faculties have comprehensive abilities that the new era endows.

For the specific organization, military civilian's ability not singly refers to an ability that is just for teaching. For the specific demands and the duties present, army civilian's ability should be the summarization of different abilities in teaching and working, among which is the ability for teaching. These abilities can be summarized as following:

\section{1) Ideological and political education}

Excellent ideological and political education is the pre-condition in carrying out every duty, which can guarantee the civilians transfer from local environment smoothly. Political belief is critical in military career teaching. Military soul awareness is the basic element in teaching.

\section{2) Teaching ability}

Teaching ability is the main activity form of class teaching organization for a teacher. Teaching ability is the special ability after graduation from universities, in working position training and in social life etc, which involves profession knowledge, language expression ability, the controlling ability in class, the wits in education and the ability of reflection.

\section{3) Scientific research ability}

Teaching is the supporting blood for academy, especially for military academy, which determines the quality of soldiers who are the main battle power in a war. Scientific research is the soul for academy's growth and development. Both teaching and research cannot be independent from each other. They are mutual affected. Scientific research is a complicated activity which needs knowledge accumulation and broad spectrum of knowledge. With the rapid development of science, the courses are crossing with each other which are interdisciplinary. The multidisciplinary cross connection is also a challenge for army civilian's teaching ability. A scientific researcher has the ability to acknowledge the latest information of some definite scientific field and contemplates the future trend development that can enable the researcher to evaluate a researcher' academic research standing and value. Scientific research is not duplicating others experiment or result but to find the difference and innovative points and to propose his own view on the research and find out his own solutions. All the pre-condition of being a successful researcher is to cultivate the researcher's awareness of creation as well as the research method training.

\section{4) Basic military cultivation}

Military teachers are excellent scholars. Besides this, they need to be familiar with military disciplines and relevant regulations. The specific military civilian determines their ability is the combination of both military cultivation and teaching quality. Military modernization construction and information of high-tech armored equipment endows military teachers the new era connotation which is the determining factor of cultivating military talents. Although military civilian are not servicemen, they carry on the same duty with them and their status has become more and more important because the community has been enlarging yearly. From the year 2018, the civilian employment has been at great expansion.

\section{The Features of Civilian Posts' Teaching Ability}

\section{A. Double Identification}

After the military reform, in the year 2018, new army civilian's regulation has been carried out. It defines that army civilian have the double identification. From nation's perspective, army civilian have the equivalent rights with state personnel who have the common university teachers responsibility. From military perspective, army civilian are not the servicemen but they undertake the military work position of management and professional position. They have the same duty with servicemen without any difference in serving for national defense. 


\section{B. Functional Mission}

After the reform military proposed mission demand. Referring to international common practice, army civilian perform corresponding responsibilities and attend military training and non-military actions in peacetime depending on need. They also carry on corresponding operation supporting tasks. They also can be enlisted into the army according to laws.

\section{Different Education Background}

Prior to the army civilian's employment, most of the faculties are with the background of military academy. They have adapted to military environment. But for the civilian's special education background and identity feature, they are short of military knowledge, but have excellent scientific research ability. They also have the political and physical quality of winning in high-tech information war.

\section{Personal ability cultivation}

The background of teaching occupation presents the development needs of civilian's post teaching ability. The development and changes happen at any moment. Especially for civilian faculty, it is of vital importance to develop personal teaching ability and the ability to serve for army. After a research questionnaire for civilian's service determination, it shows that civilian have the ability to challenging new knowledge, new technology, new achievement and new military needs. It is never too late to learn. One should be armed with knowledge to catch up with internet information development.

\section{E. Creativity ability}

The nature of employing civilian is to cut outcome and on the other hand, the attention is the civilian's creativity that have different thinking pattern with military teachers'. They are the community rich of imagination. They need to obey military construction and military situation. At the same time, they need to observe soldiers' development rules in both mental and study content. The most innovative aspect is scientific research which is the most creative theory in creating.

\section{THE THEORY FOUNDATIONS OF CIVILIAN POSTS' TEACHING ABILITY}

\section{A. Cognitive-developmental theory foundation}

The cognitive-developmental theory is proposed by Swiss psychologist Jane Piaget. According to him, the cognition is the product of the mutual affection between subject and object. The construction and development is the adaption the environment. The development of recognition not only present in knowledge accumulation but the developing level of recognition.

\section{B. The Reality of National Defense Need}

The civilian identity appearance is a product of social and military need, especially the need of national Defense. President Xi's theory the melting of military and civilian is well presented in military civilian employment. The melting will be elevated to state strategy category. The further development of the melting will release its great advantages. It is a method to carry thorough reform and flourish country as well as make military powerful. The military talents development has aroused great attention. The previous patterns cannot satisfy military development. To strengthen military construction system and to cultivate teaching abilities to satisfy new modern military talents education need, the civilian community's function would be more explicit.

\section{Psychological Need}

According to American psychologist A. H. Maslow, he proposed the theory of Hierarchy of needs that include safety needs. To feel secure at work and at home, such as living in a safe area, medical insurance, job security, financial reserve, etc. The social needs are love and belonging needs, such as friendship, intimacy, family, romantic attachment, etc. Esteem needs are the recognition and acknowledgement from others, such as internal esteem needs, self-respect and achievement, external esteem needs, social status and recognition. Self-actualization needs are the request of reaching one's full potential as a person, never fully satisfied. That means realizing personal potential, self-fulfillment, seeking personal growth, peak experience, etc.

\section{INDIVIDUAL PROMOTING STRATEGY OF ARMY CIVILIAN Posts' Teaching AbILITIES}

\section{A. To Adapt Actively to the Military Life}

Based on the needs theory, only understand the environment where you are, you can enjoy the environment. Eventually one can keep balanced attitude towards life and work. If civilian can adjust to the military environment, they can take military teaching as a lifelong journey and welcomed by soldier students. Before the adaptation, they also need to reflect the disadvantages what they need to change. For example, they are lack of military training experience and are not so familiar with soldier students' major; therefore they don't know how to make the change. In addition, the major theories studied at school cannot completely apply to the actual class environment. Then, they also need to take the advantage of cooperation with brotherhood military academy to rich their understanding for individual quick development. Next, they can widely read the interior military journals, books, military media, military meetings etc. to complete and enrich their military knowledge. During accumulation, the civilian can be aware of military developing trend and accumulate military working and teaching experience. Actively learn from the local university's advanced teaching theory and military professor's vocational spirit.

\section{B. Construct Identity Recognition}

Since the new policy carried out, civilian's identity have been accepted and well known by majority people. They generally feel the melting in military. Meanwhile, civilian should confirm the military soul awareness establish in their minds. Working in the first line of military teaching, the identity recognition had direct relationship with teaching effect.

\section{Actively Attend Scientific Research to Make Creation}

To start with setting up lifelong study belief, at present, culture cultivation and creative teaching idea have been the trend of value. Instructors and teachers have the obligation to teach knowledge, cultivate logical thinking ability, winning 
spirit and excellent psychology quality. Civilian should have strong belief, profound knowledge, flexible teaching art and command military teaching discipline to promote teaching from all aspects.

\section{Learning More Military Knowledge and Set up Military Serviceman Image}

President Xi pointed out "a famous military teacher who must be expertise in war practice" which demand military academy teaching is full of strong military color. Civilian should be the person who leads to soldier students to battle and the guider who guide them to actual war situation. Though civilian are not the serviceman, they should set up the image which is endowed more meaning. They have the obligation to realize the specific career that should be all about military teaching material in class and more about the latest military information.

\section{CONCLUSIONS}

By analyzing the connotation of the post teaching ability and the connotation and construction of the military civilian's post teaching ability, the basics and necessities of being military civilian's teaching are arrived. The paper also analysis the theories which are the most influential theory cognitive-developmental theory, psychological need theory and national defense need. It also gives the features of civilian the special community. Based on the connotation and theories, the promotion strategies have been proposed from the civilian's perspective. Because of people's patriotic enthusiasm, civilian can realize he is the person whose individual power is great. Adding their identification identified, they are military servicemen, but have more duty than them. During analysis it also refers to the promotion of local university teachers and serviceman faculty's teaching ability. Facing the fast development, the civilian can strongly feel how important the scientific research and the creation. In verse, they mutual affect each other. Military soldier students are the backbones of military which make military faculty teach for winning in wars. The core of teaching is teaching for fighting. Teaching serves for fighting. The strategy is expected to improve the current civilian's teaching ability, and based on this more completed strategy is hoping to construct to cultivate more talents for national defense.

\section{REFERENCE}

[1] Gao Xiang, A study of the U.S. fifth generation of defense language proficiency test $[\mathrm{J}]$. Engineering college of PLA: Journal of Naval University of Engineering, 2012(9-4)92-96.

[2] Army to enhance civilian career programs AUSA News [J] Special reports, 2008.

[3] Paul Stone, Civilian personnel Downsizing Painful, successful [N] AIR FORCE NEWS SERVICE.2 AUG, 1999.

[4] Lenski, G.E.Power and Privilege: A Theory of Social Stratification [M]Chpek Hill: University of North Carolina Press, 1984.

[5] Zhang Junying. Consideration and practice of allowance system for military academy faculty $[\mathrm{J}]$. Journal of Higher Education. 2018(31-4)37-39.

[6] The policy for civilian personnel of PLA, 2017. 09. 27. 